\title{
EARLY DETECTION OF MILD COGNITIVE IMPAIRMENT IN PATIENTS WITH CEREBROVASCULAR DISEASE
}

\author{
Irena Martinić-Popović, Vesna Šerić and Vida Demarin
}

\begin{abstract}
University Department of Neurology, Sestre milosrdnice University Hospital, Zagreb, Croatia
SUMMARY - Evaluation of mild cognitive impairment (MCI) is important because it can enable early medical management in order to prevent severe dementia of Alzheimer's or vascular type. In this pilot study, patients admitted to University Department of Neurology for first ever stroke/transient ischemic attacks (patient group, $\mathrm{N}=81$, mean age $56 \pm 7.0$ years) and control subjects without signs of cerebrovascular disease (CVD) but with vascular risk factors present (control group, $\mathrm{N}=45$, mean age $53 \pm 6.0$ years) were tested by use of Mini Mental State Exam (MMSE) and Montreal Cognitive Assessment (MoCA) on admission, and retested at three and six months. In all study subjects standard brain computed tomography, color Doppler flow imaging of carotid arteries with intima-media thickness (IMT) measurement and transcranial Doppler sonography (TCD) were performed. Multiple risk factors were present in $56(69.1 \%)$ patients. Arterial hypertension, hyperlipoproteinemia and diabetes mellitus were most common diagnoses in control subjects. All study subjects had normal initial MMSE, whereas MoCA score was decreased (<26 points) in $52(57.2 \%)$ patients and $23(9.6 \%)$ control subjects. Six months later, the mean MoCA score was 18.87 and mean MMSE 25.25 in patient group. Patients with stroke and multiple risk factors showed a statistically significant cognitive decline in comparison to patients with transient ischemic attacks. At six months, the greatest cognitive decline in patient group was recorded in patients with arterial hypertension and increased IMT. In subjects with cerebrovascular risk factors, early signs of cognitive impairment exist even before the cerebrovascular disease becomes clinically evident. MoCA proved to be an appropriate tool for cognitive evaluation of patients with mild cognitive impairment of vascular type.
\end{abstract}

Key words: Brain - pathology; Brain - physiopathology; Cerebrovascular disease - diagnosis; Dementia - Alzheimer disease; Dementia - vascular dementia ???

\section{Introduction}

The term mild cognitive impairment (MCI) refers to a transitional stage between cognitive changes of normal aging and dementia, of both Alzheimer's and vascular type. During this stage, cognitive decline is subtle and of insufficient severity to constitute dementia, yet it is beyond for what is expected for normal aging. In so called amnesic MCI the patient has subjective memory complaints which are corroborated by an informant, ab-

Correspondence to: Irena Martinić-Popoví, MD, University Department of Neurology, Sestre milosrdnice University Hospital, Vinogradska c. 29, HR-10000 Zagreb

CroatiaE-mail: irene@post.htnet.hr

Received December 13, 2005, accepted in revised form May 11, 2006 normal memory function relative to age and education norms but essentially normal general function as well as normal activities of daily living ${ }^{2}$. Previous studies have shown a conversion rate of MCI to Alzheimer's disease (AD) of 10\%-15\% per year ${ }^{3}$. Amnesic MCI can be caused by multiple etiologies such as degenerative changes of neurons, which most likely lead to AD. Additionally, multiple and critically placed infarctions of the brain also eventually lead to mild cognitive decline as a premonitory state of vascular dementia ${ }^{4}$. Although it is well known that vascular risk factors have measurable negative effects on the brain and cognitive abilities ${ }^{5}$, recent data show numerous similarities in vascular and inflammatory risk factors, such as C-reactive protein and fibrinogen, contributing to the pathogenesis of both vas- 
cular and Alzheimer's dementia. ${ }^{6}$ So, in addition to simple coexistence, vascular dementia and AD seem to have closer interaction, and they also share common pathogenic mechanisms such as delayed neuronal death and apoptosis ${ }^{4,5}$. Evaluation of early signs of cognitive decline is important because many of the risk factors leading to cerebrovascular disease (CVD) can be managed medically in order to prevent severe cognitive impairment. The simplicity of evaluation procedures will gain even more importance in the future, due to the increase in the proportion of elderly persons in the population. In assessment of MCI patients, a wide battery of neuropsychological testing is commonly use ${ }^{7,8}$. Neuropsychological testing with standardized tests, however, often presents a problem to clinicians for its complicated and time-consuming nature. Mini-Mental-State-Examination (MMSE) ${ }^{9}$ is still most widely used in assessment of patients with memory complaints, although it lacks sensitivity in detecting MCI or early stages of dementia ${ }^{8,10}$. Most individuals meet the clinical criteria for MCI score above 26 points on the MMSE, which is also the normal range for elderly individuals. Montreal Cognitive Assessment (MoCA), which has recently been developed by Nasreddine et al., is an easy to administer and brief screening tool with high sensitivity and specificity for MCI ${ }^{11}$. While MMSE is superior for more advanced stages of cognitive decline, MoCA is useful for the mild stages of cognitive impairment and for distinguishing patients with MCI from cognitively intact patients, which makes it a practical tool for first-line physicians ${ }^{11}$. A previous study assessed superior sensitivity and specificity of MoCA in detection of MCI and early stages of $\mathrm{AD}^{11}$.

In this pilot study, we used both MMSE and MoCA to compare the incidence and severity of mild cognitive changes in patients with first clinical signs of CVD and in subjects with one or more cerebrovascular risk factors, with no clinical signs of cognitive decline. Apart from routinely assessed cerebrovascular risk factors (age, sex, arterial hypertension, diabetes, hyperlipoproteinemia, cigarette smoking and alcohol consumption, obesity), in our study we also used B-mode ultrasound for assessment of the intima-media thickness (IMT) of extracranial carotid arteries. IMT can be assessed in a relatively simple way and represents a safe, inexpensive, precise and reproducible measure ${ }^{12}$. IMT is considered to be an independent vascular risk factor ${ }^{13}$. The predictive value of IMT with regard to cardiovascular complications has been established in several prospec- tive studies, and suggests that IMT measurement may in the future participate in the stratification of vascular risk of asymptomatic patients in primary prevention ${ }^{13,14}$. We also used transcranial Doppler sonography (TCD) for measurement of mean blood flow velocities (MBFV) in basal cerebral arteries as a noninvasive and simple diagnostic tool for assessment of cerebral hemodynamics $^{15}$. Previous studies have shown that cerebral hemodynamics may be reduced in patients who develop dementia at a later stage ${ }^{16}$.

\section{Subjects and Methods}

Two groups of subjects were recruited from University Department of Neurology, Sestre milosrdnice University Hospital in Zagreb. Patient group consisted of 81 subjects (mean age $56 \pm 7.0$ years) admitted to the Department for first cerebrovascular incident (first ever stroke or transient ischemic attacks (TIA)). TIA was diagnosed according to redefined diagnostic criteria of the TIA Working Group ${ }^{17}$. Control group consisted of 45 subjects treated as outpatients (mean age $53 \pm 6.0$ years), with no clinical signs of CVD but with one or more vascular risk factors present. None of study subjects had any subjective or objective memory complaints prior to enrolment. Upon giving an informed consent, both groups were tested using standard $\mathrm{MMSE}^{9}$ and $\mathrm{MoCA}^{11}$. MMSE requires 5-10 minutes for administration. It is composed of items assessing orientation, immediate and delayed recall of three words, naming, phrase repetition, the ability to follow simple commands, writing, visuospatial function, attention and mental control. Total MMSE score of 25-30 is considered normal, while scores below 24 points indicate dementia ${ }^{9,18}$. MoCA was translated to Croatian and administered according to administration and scoring instructions given by the authors ${ }^{11}$. It is a 30-point test that takes approximately 30 minutes to administer. The short-term memory recall task (5 points) involves two learning trials of five nouns and delayed recall after approximately 5 minutes. Visuospatial abilities are assessed using a clock-drawing task (3 points) and three-dimensional cube copy (1 point). Multiple aspects of executive functions are assessed using an alteration task adapted from the Trial Making B task (1 point), a phonemic fluency task (1 point), and a twoitem verbal abstraction task ( 2 points). Attention, concentration and working memory are evaluated using a sustained alteration task (target detection using tapping, 1 point), serial subtraction task (3 points) and digits for- 
ward and backward (1 point each). Language is assessed using a three-item confrontation naming task with lowfamiliarity animals (lion, camel, rhinoceros; 3 points), repetition of two syntactically complex sentences (2 points) and the aforementioned fluency task. Finally, orientation to time and place is evaluated (6 points) ${ }^{11}$. MMSE and MoCa were administered to both groups on admission and repeated at three and six months. In all subjects, data on conventional vascular risk factors were recorded, including data on age and sex, arterial hypertension, diabetes, hyperlipoproteinemia, cigarette smoking, alcohol consumption, and obesity. Additional data were collected on cardiovascular risk factors/disease (CVD), including coronary heart disease, congestive heart failure, peripheral vascular disease, atrial fibrillation, left ventricular hypertrophy, and cardiac arrhythmias. In addition to standard brain CT scan, CDFI of carotid arteries with IMT measurement as another diagnostic tool in the assessment of cerebrovascular risk were performed in all subjects on admission. CDFI and IMT measurement were done on commercially available equipment (Aloka Prosound SSD-550) with a linear $8 \mathrm{MHz}$ transducer. Besides standard CDFI of both common carotid arteries (CCA), internal carotid arteries (ICA) and external carotid arteries (ECA), IMT was measured in the near and far walls of the three main segments of extracranial carotid arteries (CCA, carotid bifurcation and ICA) on both sides ${ }^{12,13}$. For each segment, ultrasound scan is performed in more than one direction, the maximum value of IMT is selected, and the final IMT is considered the mean of IMT values at the 12 sites examined. Measurements of IMT were done on the basis of video image by visual assessment of the leading edges (the upper demarcation line) of the bloodintima and media-adventitia interfaces defining IMT. The analysis was performed off-line manually with the assistance of computerized program, by placing the cursor on the interfaces in the digitalized video image ${ }^{13,14}$. IMT values above $0.8 \mathrm{~mm}$ were considered pathologi$\mathrm{cal}^{19}$. Assessment of cerebral hemodynamics was done by use of TCD, which was performed on commercially available equipment using $2 \mathrm{MHz}$ probe. Transtemporal approach was used to evaluate cerebral hemodynamics of the circle of Willis, while subforaminal approach was used for insonation of terminal vertebral and basilar arteries. The key flow parameters, which include the mean flow velocity (MFV), pulsaltility index (PI) and direction of flow in the ophthalmic artery, were recorded for each participant and either side, according to a well defined diagnostic protocol ${ }^{20}$. TCD findings were classified as normal if registered MBFV in all insonated cerebral arteries were within the age-adjusted normal range $^{12}$. All Doppler ultrasound examinations (CDFI of carotid arteries with IMT measurement and TCD) were done and interpreted by an experienced physician trained in Doppler ultrasound assessment. In order to assess the nature of cerebrovascular disorder (TIA/ stroke), apart from clinical picture, CT scan of the brain was performed in all patient group subjects immediately upon admission, using a Siemens-Sensation Multislice Computed Tomography scanner with 16-row detector layer, according to standard protocol (non-enhanced scans with a slice thickness of $5 \mathrm{~mm}$ ). Control group subjects also underwent brain CT scan as part of neurological diagnostic procedures. Brain CT scan in controls was performed within two weeks of enrolment. Brain CT findings were classified as positive if signs of ischemic stroke were present.

Prior to any further analysis, all data sets were analyzed for normality using Kolmogorov-Smirnov test, and are presented as median \pm interquartile range (IQ) for data that were not normally distributed, and as mean \pm standard deviation for data that were normally distributed. Normally distributed data sets were analyzed using Student's t-test. Non-normally distributed data sets were analyzed using parametric One-Way Analysis of Variance on Ranks (ANOVA on Ranks) Mann-Whitney Rank Sum Test, post hoc analysis was performed using all pair-wise multiple comparison procedures (HolmSidak method). Difference was considered to be statistically significant at $\mathrm{p}<0.001$.

There were no statistically significant differences either between MMSE and MoCA values measured at baseline (0 months) and at three months, or between MMSE and MoCA values measured at three and six months. Our results therefore present the analysis of cognitive results as assessed at baseline (0 months) and at six months.

\section{Results}

\section{Study populations}

There were $62(76.54 \%)$ acute stroke patients and $19(23.46 \%)$ TIA patients enrolled in the patient group versus 45 control group subjects with no clinical evidence of CVD but with the presence of one or more cerebrovascular risk factors. There were no statistically signifi- 
Table 1. Study subject demographics

\begin{tabular}{lcccc}
\hline & & $\begin{array}{l}\text { Age } \\
(\mathrm{yrs})\end{array}$ & Education & $\begin{array}{r}\text { Female } \\
(\%)\end{array}$ \\
\hline & $\mathrm{n}$ & Mean & \pm & $\mathrm{SD}$ \\
\hline Patient group & 81 & $55.60 \pm 7.48$ & $11.02 \pm 4.12$ & $35(43)$ \\
TIA & 19 & $53.45 \pm 4.35$ & $10.05 \pm 3.15$ & $7(37)$ \\
Stroke & 62 & $59.80 \pm 6.78$ & $10.82 \pm 3.77$ & $12(63)$ \\
Control group & 45 & $53.30 \pm 6.05$ & $12.08 \pm 3.28$ & $23(51)$ \\
\hline
\end{tabular}

TIA, transient ischemic attack

cant between-group differences according to age, sex and education (patient group including stroke patients and TIA patients, and control group). In all control group subjects brain CT scan results were normal, free from any signs of CVD. A previous study indicated the subjects with 12-year education or less had worse performance on MoCA, so 1 point was added to their total MoCA score (if total MoCA score $<30)^{11}$. Demographic data are summarized in Table 1.

The vascular risk factor profile according to the $\mathrm{Na}$ tional Stroke Association (NSA) Stroke Prevention Guidelines, with the addition of data on TCD results, IMT values and multiple risk factors $(>2)$ for both patient and control groups are shown in Table 2. Multiple risk factors were present in $56(69.1 \%)$ patients versus $23(57.7 \%)$ control subjects. Also, multiple risk factors were present in $46(74.2 \%)$ stroke patients versus ten $(52.6 \%)$ TIA patients. As shown in Table 2, in asympto-

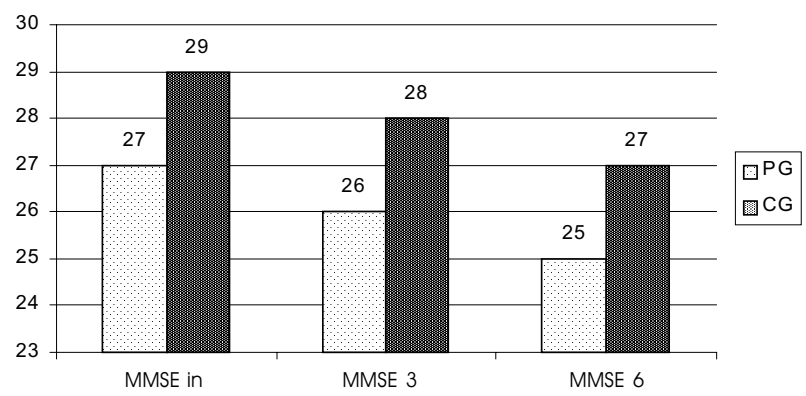

Fig. 1. Mean MMSE values in patient group $(P G)$ and control group $(C G)$ on admission (MMSE in), and at three and six months (MMSE 3/MMSE 6).

matic subjects (control group), arterial hypertension was most commonly recorded $(n=31 ; 68.8 \%)$, followed by hyperlipoproteinemia $(n=26 ; 57.7 \%)$ and diabetes mellitus $(n=23 ; 51.1 \%)$. Increased IMT $(n=16 ; 84.2 \%)$, diabetes $(n=12 ; 63.1 \%)$ and previous/current smoking $(n=12 ; 63.1 \%)$ were most often recorded in TIA patients, whereas arterial hypertension $(n=51 ; 82.2 \%)$, increased IMT $(n=40 ; 64.5 \%)$ and previous/current smoking $(n=39 ; 62.9 \%)$ predominated in stroke patients.

\section{Cognitive results as assessed by MMSE and MoCA}

As illustrated by the mean values in Figure 1, the initially normal mean MMSE scores in both patient and control groups remained within the normal range at three

Table 2. Vascular risk factors in patient group (TIA/stroke), TIA patients, stroke patients, and control group

\begin{tabular}{lcccc}
\hline & $\mathrm{P}$ a t i e $\mathrm{n} \mathrm{t}$ g r o u p & Control group \\
\hline & TIA/stroke & TIA & Stroke & $(\mathrm{N}=45)$ \\
& $(\mathrm{N}=81)$ & $(\mathrm{N}=19)$ & $(\mathrm{N}=62)$ & $\mathrm{n}(\%)$ \\
\hline Arterial hypertension & $\mathrm{n}(\%)$ & $\mathrm{n}(\%)$ & $\mathrm{n}(\%)$ & $31(68.8)$ \\
Hyperlipoproteinaemia & $62(76.5)$ & $11(57.8)$ & $51(82.2)$ & \\
total cholesterol $>5.2 \mathrm{mmol} / \mathrm{L})$ & & & & \\
Diabetes mellitus & $42(51.8)$ & $9(47.3)$ & $33(53.2)$ & $26(57.7)$ \\
Obesity & $48(59.2)$ & $12(63.1)$ & $36(58.1)$ & $23(51.1)$ \\
Previous or current smoking & $29(35.8)$ & $11(57.8)$ & $18(29.0)$ & $17(37.7)$ \\
Coronary disease & $51(62.9)$ & $12(63.1)$ & $39(62.9)$ & $21(46.6)$ \\
Atrial fibrillation & $16(12.7)$ & $7(36.8)$ & $9(14.5)$ & $6(13.3)$ \\
Increased IMT (>0.8 mm) & $17(20.9)$ & $9(43.7)$ & $8(12.9)$ & $8(17.7)$ \\
Hypoperfusion (TCD) & $56(69.1)$ & $16(84.2)$ & $40(64.5)$ & $19(42.2)$ \\
Multiple risk factors $(>2)$ & $43(53.0)$ & $7(36.8)$ & $36(58.0)$ & $17(37.7)$ \\
\hline
\end{tabular}

TIA, transient ischemic attack; TCD, transcranial Doppler 


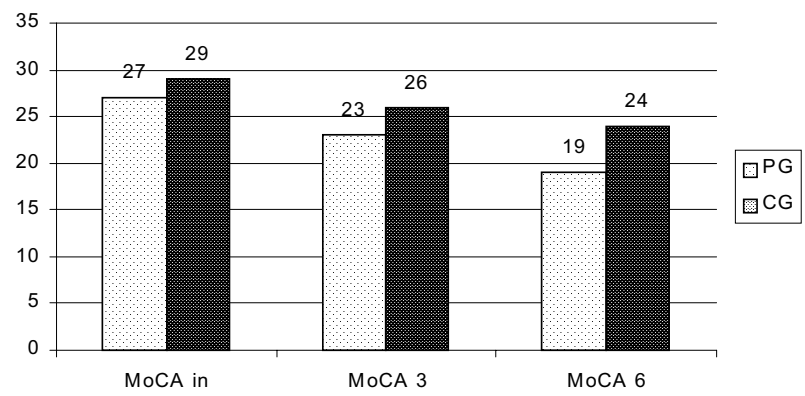

Fig. 2. Mean MoCA values in patient group $(P G)$ and control group $(C G)$ on admission (MoCA in), and at three and six months (MoCA 3/MoCA 6).

and six months. When MoCA was used, as shown in Figure 2, the initial mean scores for both groups were normal as well. In patient group, the mean MoCA scores at three and six months were below normal values $(<26)$. In control group, the mean MoCA score approached the cut-off score (mean 26.67; SD 1.575) at three months, dropping to clearly abnormal values at six months of initial testing (mean 24.47; SD 1.302).

As shown in Figures 1 and 2, cognitive performance on MMSE for both groups fell within the normal range throughout the study period and the administration of MoCA revealed early cognitive abnormalities, i.e. at three months only in patient group, and at six months in both patients and control groups.

\section{Relationship of cerebrovascular disease, vascular risk factors and cognitive performance}

Patient group subjects were divided into subgroups according to the nature of their CVD (TIA or first ever stroke) and vascular risk factors recorded. Cognitive results of particular subgroups were further analyzed. When MoCA was used, the subgroup of patients who had sustained a stroke and had multiple vascular risk factors $(>2)(\mathrm{N}=34 ; 54.8 \%)$ showed a statistically significant cognitive decline at six months (mean $\mathrm{MoCA}_{6}=17.88$; SD 0.532) as compared with TIA patients $\left(\mathrm{N}=19 ; 23.45 \%\right.$; mean $\mathrm{MoCA}_{6}=24.37$; SD 0.798; $\mathrm{p}<0.001)$. On the contrary, comparison of the mean MoCA scores between TIA patients and control subjects yielded no statistically significant difference (mean $\mathrm{MoCA}_{(\mathrm{CG})}=26.67 ; \mathrm{SD} 0.71 ; \mathrm{p}=0.023$ ).

As shown in Figure 3, in control group the greatest cognitive decline at six months was recorded in the subgroups of subjects with arterial hypertension (mean $\mathrm{MoCA}_{6(\mathrm{CG}-\mathrm{AH})}=22.34 ;$ SD 0.79), increased IMT (mean

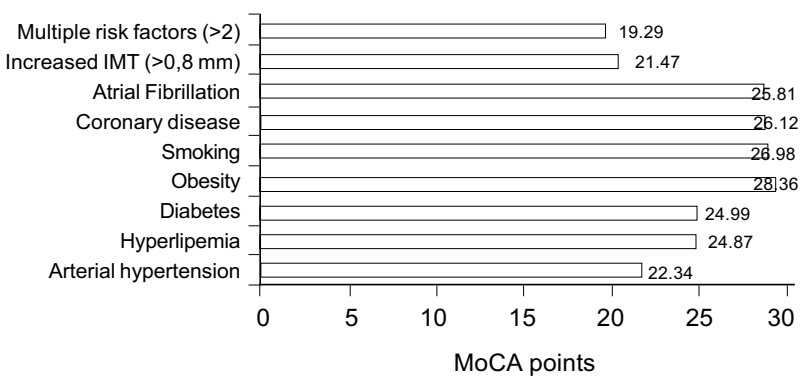

Fig. 3. Mean MoCA scores in control group according to risk factors at six months.

$\left.\mathrm{MoCA}_{6(\mathrm{CG}-\mathrm{IMT})}=21.47 ; \mathrm{SD} 1.003\right)$ and multiple vascular risk factors (mean $\mathrm{MoCA}_{6(\mathrm{CG}-\mathrm{MRF})}=19.29 ; \mathrm{SD} 1.32$ ).

In order to compare the overall cognitive decline as measured by MMSE and MoCA for both patient and control groups over the six-month period, $\Delta$ mean values for MMSE ( $\triangle$ MMSE $=$ MMSE $0-$ MMSE 6$)$ and MoCA scores $(\triangle \mathrm{MoCA}=$ MoCA $0-$ MoCA 6$)$ were calculated for the patient and control subgroups with different vascular risk factors and then used on further calculations. Table 3 presents cognitive decline as assessed by MoCA $(\triangle \mathrm{MoCA})$ in patient and control subgroups with different vascular risk factors (present or absent). In patient group, the subgroup with multiple risk factors showed a statistically significant cognitive decline when compared to patients with only one or two risk factors present. Also, in the subgroup of patients with cerebral hypoperfusion as assessed by TCD a statistically significant cognitive decline was found when compared to patients with normal TCD findings. In control group, $\triangle \mathrm{MoCA}$ yielded a statistically significant difference among subjects with arterial hypertension, subjects with coexisting arterial hypertension and increased IMT values, and subjects with coexisting arterial hypertension and multiple risk factors. When MMSE was used, there were no statistically significant differences in the rate of cognitive decline ( $\triangle \mathrm{MMSE}$ ) among the patient and control subgroups with or without particular vascular risk factors.

\section{Discussion}

Given the increased number of elderly population, dementia of any type (both CVD and $\mathrm{AD}$ ) today presents a very common and devastating illness, and efforts are made to enable the earliest diagnosis and treatment possible. Our results indicated the first measurable signs of cognitive malfunction to exist even before the dis- 
Table 3. Cognitive decline as assessed by MoCA ( $\triangle$ MoCA) in patient and control subgroups with different vascular risk factors (ANOVA, Mann-Whitney Rank Sum test, t-test)

\begin{tabular}{|c|c|c|c|c|c|c|c|c|}
\hline \multicolumn{9}{|c|}{$\Delta$ MoCA } \\
\hline \multirow[t]{2}{*}{$\mathrm{CV}$ risk factors } & \multicolumn{4}{|c|}{$\mathrm{Pat}$ i e $\mathrm{nt}$ grou } & \multicolumn{4}{|c|}{ Con trol grou p } \\
\hline & median & $25 \%$ & $75 \%$ & $\mathrm{p}$ & median & $25 \%$ & $75 \%$ & $\mathrm{p}$ \\
\hline $\mathrm{AH}+$ & 7.0 & 5.0 & 8.0 & 0.983 & - & - & - & $<0.001^{*}$ \\
\hline $\mathrm{AH}-$ & 7.0 & 6.0 & 8.0 & & - & - & - & $(\mathrm{t}$-test $)$ \\
\hline Hyperlipoproteinemia + & 7.0 & 6.0 & 8.0 & 0.174 & 4.0 & 3.0 & 4.0 & 0.605 \\
\hline Hyperlipoproteinemia - & 6.0 & 5.0 & 8.0 & & 4.0 & 3.0 & 5.0 & \\
\hline $\mathrm{DM}+$ & 7.0 & 6.5 & 9.0 & 0.057 & 4.0 & 3.0 & 5.5 & 0.250 \\
\hline DM - & 7.0 & 5.0 & 8.0 & & 4.0 & 3.0 & 4.0 & \\
\hline Obesity + & 7.0 & 6.0 & 8.0 & 0.201 & 4.0 & 2.8 & 4.5 & 0.639 \\
\hline Obesity - & 7.0 & 5.0 & 8.0 & & 4.0 & 3.0 & 5.0 & \\
\hline Smoking + & 7.0 & 5.0 & 8.0 & 0.619 & 4.0 & 3.0 & 4.0 & 0.772 \\
\hline Smoking - & 7.0 & 5.0 & 8.0 & & 4.0 & 3.0 & 5.0 & \\
\hline Coronary disease + & 7.0 & 5.0 & 8.0 & 0.441 & 3.5 & 3.0 & 5.0 & 0.676 \\
\hline Coronary disease - & 7.0 & 5.0 & 8.0 & & 4.0 & 3.0 & 4.8 & \\
\hline $\mathrm{AF}+$ & 7.0 & 5.0 & 8.0 & 0.372 & 4.0 & 3.0 & 4.0 & 0.469 \\
\hline $\mathrm{AF}-$ & 7.0 & 5.0 & 8.0 & & 4.0 & 3.0 & 5.0 & \\
\hline $\mathrm{IMT}>8 \mathrm{~mm}+$ & 7.0 & 5.0 & 8.8 & 0.071 & 4.0 & 3.0 & 4.0 & 0.564 \\
\hline IMT > 8 mm - & 7.0 & 5.0 & 7.8 & & 4.0 & 3.0 & 5.0 & \\
\hline $\operatorname{MRF}(>2)+$ & 7.0 & 6.0 & 8.0 & $<0.001^{*}$ & 4.0 & 3.0 & 4.0 & 0.741 \\
\hline $\operatorname{MRF}(>2)-$ & 6.0 & 5.0 & 7.0 & & 4.0 & 3.0 & 5.0 & \\
\hline Hypoperfusion (TCD) + & 7.0 & 6.0 & 9.0 & $<0.001^{*}$ & 4.0 & 3.0 & 4.0 & 0.480 \\
\hline Hypoperfusion (TCD) - & 6.0 & 5.0 & 7.0 & & 4.0 & 3.0 & 5.0 & \\
\hline$(\mathrm{AH}+\mathrm{IMT}>8 \mathrm{~mm})+$ & 7.0 & 5.0 & 8.0 & 0.385 & 4.0 & 3.0 & 4.0 & $<0.001^{*}$ \\
\hline$(\mathrm{AH}+\mathrm{IMT}>8 \mathrm{~mm})-$ & 7.0 & 5.3 & 7.8 & & 1.0 & 1.3 & 2.8 & \\
\hline$(\mathrm{AH}+\mathrm{MRF}>2)+$ & 7.0 & 5.3 & 8.0 & 0.069 & 4.0 & 3.0 & 5.0 & $<0.001^{*}$ \\
\hline$(\mathrm{AH}+\mathrm{MRF}>2)-$ & 7.0 & 5.1 & 7.8 & & 2.75 & 2.0 & 6.0 & \\
\hline
\end{tabular}

$\mathrm{AH}$, arterial hypertension; DM, diabetes mellitus; AF, atrial fibrillation; IMT, intima-media thickness; IMT >8 mm, increased IMT values; Hypoperfusion (TCD), cerebral hypoperfusion as assessed by transcranial Doppler; MRF, multiple risk factors; *statistically significant difference

ease itself had become clinically evident in patients with CVD. Cognitive follow up using MoCA during a sixmonth period in both patients with first cerebrovascular event (first ever stroke or TIA) and controls free from CVD symptoms showed a step-wise reduction of cognitive performance in both groups, with a more pronounced and more rapid decline in the patient group (Fig. 2). However, discrete cognitive changes were also present in asymptomatic controls, where subjects with multiple risk factors, arterial hypertension and increased IMT had the most pronounced cognitive decline at six months. It appears that the concurrent presence of multiple vascular risk factors additionally increases the risk of subtle cognitive decline through possible interaction of risk factors, even in subjects without evident clinical signs of MCI. We believe this finding could be explained by small-vessel disease, which is likely to be present in these individuals due to persistent damage to the small terminal vasculature of subcortical cerebrum caused by different vascular risk factors. Small-vessel disease is known to be closely linked to hypertension and is an indicator of atherosclerotic disease ${ }^{21}$. This observation is consistent with the results reported by Prinse $e t a l$., suggesting that in the elderly cerebral small-vessel disease contributes to cognitive decline by affecting information processing speed and executive function ${ }^{16}$. A previous study assessing cerebral vasoreactivity in patients with multi-infarct dementia using TCD and acetazola- 
mide testing demonstrated impaired cerebrovascular hemodynamics ${ }^{22}$, while some early prospective studies also showed that patients who developed vascular dementia may have had reduced cerebral blood flow for some years before any clinical evidence of dementia ${ }^{23}$. CVD is a common symptom of the aging process and several studies have recently suggested that cerebrovascular risk factors are strongly associated with dementia $^{18,24}$. Symptomatic CVD can easily be recognized by the presence of associated conditions and by use of brain imaging. It is well known that white matter hyperintensities are associated with extracranial carotid disease, and results reported by Rilley et al. suggest that even in the absence of macrosopic infarctions, individuals with evidence of severe atherosclerotic disease in the circle of Willis are at a greater risk of memory-related $\mathrm{MCI}^{25}$. The NINCDS-ADRDA criteria state that the diagnosis of probable $\mathrm{AD}$ requires the absence of systemic disorders or other brain disease that could alone account for the dementia, but there are no specifications on how to diagnose probable AD with concomitant $\mathrm{CVD}^{26}$. Dementias were previously often classified on the basis of the presence or absence of CVD or stroke, with positive associations between stroke risk factors and VAD, and negative associations between stroke and $\mathrm{AD}^{25}$. However, in the large majority of elderly patients diagnosed with dementia cortical infarctions and senile plaques with neurofibrillary tangles are simultaneously present. This condition in which Alzheimer's and vascular pathology overlap is described as mixed dementia. Given recent epidemiological and experimental data, it appears that there are many reasons to consider the role of vascular factors in the initiation, promotion and progression of AD. According to latest studies, common risk factors for AD and VAD are now recognized, including age, family history of dementia, previous TIA or stroke, atherosclerosis with coronary heart disease, elevated or low systemic blood pressure, diabetes type 2 , hypercholesterolemia, hyperhomocystinemia, smoking, and presence of apolipoprotein E epsilon 4 (apoE4) allele ${ }^{24}$. As vascular pathology appears to be a common characteristic of both VAD and AD, we emphasize the importance of early and accurate diagnosis of mild cognitive decline in order to recognize the patients in whom strict medical control of vascular risk factors could prevent or at least delay clinically evident dementia of any type. Validation study by Nasreddine et al. showed MoCA to have excellent sensitivity in detecting MCI (90\%) and mild stages of $\mathrm{AD}(100 \%)$, and considerably higher sensi- tivity than MMSE ${ }^{11}$. In our study, MoCA also demonstrated the ability of detecting discrete cognitive changes in symptom-free patients with no cognitive complaints but with an increased cerebrovascular risk (Fig. 2). When cognitive follow up using MMSE was done, we found only initial signs of cognitive decline in patient group at six months, while no abnormalities were detected in asymptomatic controls. Both of these findings are consistent with the results of our previous study $^{27}$. Thus, our results corroborate superior sensitivity of MoCA in detecting MCI, previously reported by others ${ }^{11}$. The features of MoCA design which probably explain its sensitivity compared to MMSE are memory testing which involves more words, fewer learning trials, and longer delay before recall than MMSE ${ }^{11}$. Visuospatial processing, executive functions and language abilities are tested by MoCA with more numerous and demanding tasks than by MMSE ${ }^{11}$. As the role of vascular factors in the initiation, promotion and progression of both vascular dementia and AD, and the understanding of overlap between vascular and degenerative pathology has recently become more clear, these data further support the importance of tight control of vascular risk factors in both symptomatic and asymptomatic patients, which is essential in the prevention of severe dementia $^{28,29}$.

The increased risk of developing significant cognitive impairment in patients with stroke/TIA has been well documented ${ }^{26}$. In our study, we detected mild cognitive decline in cerebrovascular symptom-free individuals, which indicates that neuronal damage due to the presence of vascular risk factors occurs long before the disease has become evident. This observation further supports the latest concept of an increased incidence of mixed dementias that were considered to be rare in the past $^{27,28}$. A recent study showed that neither Short Test of Mental Status (STMS) nor MMSE could be used alone to diagnose MCI or dementia ${ }^{30}$.

Apart from MoCA, there are currently no other screening tools to quickly and reliably distinguish MCI from normal controls, so MoCA is recommended for use in patients with normal range score on $\mathrm{MMSE}^{11}$. As it appears today, the current concept of purely vascular or purely Alzheimer's dementia has outlived its usefulness with the increasing recognition of mixed dementias ${ }^{31}$. The interaction of vascular components and other components more than doubles the rates of progression when compared to pure AD alone $e^{28,31}$. 
Our study results are consistent with current research moving towards early identification of subjects in presymptomatic stage, which has been termed "brain-atrisk" and is most appropriate for early primary and secondary preventive therapy ${ }^{31}$. We demonstrated the use of MoCA to allow for simple and early recognition of subtle cognitive decline in apparently mentally healthy individuals, making it an important tool for cognitive follow up and also for investigation of treatments aimed at secondary prevention of severe dementia.

\section{References}

1. PETERSEN RC, editor. Mild cognitive impairment: aging to Alzheimer's disease. New York : Oxford University Press, 2003.

2. PETERSEN RC, KNOPMAN DS, BOEVE BF, PARISI JE, DICKSON DW, IVNIK RJ $e$ t al. Mild cognitive impairment update 2002. In: IQBAL K, WINBLAD B, eds. Alzheimer's disease and related disorders: research advances. Bucharest: Ana Aslan International Academy of Aging, 2003:111-9.

3. PETERSEN RC. Conceptual overview. In: PETERSEN RC, ed. Mild cognitive impairment: aging to Alzheimer's disease. New York: Oxford University Press, 2003:1-4.

4. GORRELICK PB. Prevention . In: BOWLER JV, HACHINSKI $\mathrm{V}$, eds. Vascular cognitive impairment: preventable dementia. New York: Oxford University Press,2003:308-20.

5. SKOOG I, KALARIA RN, BRETLER MMB. Vascular factors and Alzheimer's disease. Alzheimer Dis Assoc Disord 1999;13 (Suppl 3):S106-14.

6. GALASKO D, CHANG L, MOTTER R, CLARK CM, KAYE J, KNOPMAN D et al. High cerebrospinal fluid tau and low amyloid â42 levels in the clinical diagnosis of Alzheimer's disease and relation to apolipoprotein E genotype. Arch Neurol 1998;55:937-45.

7. CHERTKOW H. Mild cognitive impairment. Curr Opin Neurol 2002;15:401-7.

8. THOMPSON H, HODGES J. Mild cognitive impairment: a clinically useful but currently ill-defined concept? Neurocase 2002;8:405-10.

9. FOLSTEIN MF, FOLSTEIN SE, McHUGH PR. "Minimental-state". A practical method for grading the cognitive state of patients for the clinician. J Psychiatr Res 1975;2:189-98.

10. TOMBAugh TN, McINTYRE NJ. The Mini-Mental State Examination: a comprehensive review. J Am Geriatr Soc 1992;40:922-35.

11. NASREDDINE ZS, PHILIPS NA, BEDIRIAN V, GHARBONNEAU S, WHITEHEAD V, COLLIN I, GUMMINGS JL, CHERTKOW H. The Montreal Cognitive Assessment, MoCA: a brief screening tool for mild cognitive impairment. J Am Geriatr Soc 2005;53:695-9.

12. HOWARD G, SHARRETT AR, HEISS G, EVANS GW, CHAMBLESS LE, RILEY WA, BURKE GL. Carotid artery intimal-medial thickness distributions in general populations as evaluated by B-mode ultrasound. ARIC Investigators. Stroke 1993;9:1297-304.

13. SIMON A, LEVENSON J. Intima-media thickness, a new tool for diagnosis and treatment of cardiovascular risk. J Hypertens 2002;20:159-69.

14. GREENLAND P, ABRAMS J, AURIGEMMA FP, BOND MG, CLARK LT, CRIQUI MH, CROUSE JR $3^{\text {rd }}$, FRIEDMAN ?, FUSTER V, HERRINGTON DM, KULLER LH, RIEDKER PM, ROBERTS WC, STANDFORD W, STONE N, SWAN HJ. Prevention conference V: Beyond secondary prevention identifying the high-risk patient for primary prevention: noninvasive tests of atherosclerotic burden; Writing Group III. Circulation 2000;101:E16-22.

15. AASLID R, MARKWALDER TM, NORNES H. Non-invasive transcranial doppler ultrasound recordings of flow velocities in basal cerebral arteries. J Neurosurg 1982;57:769-74.

16. PRINS ND, van DIJK EJ, den HEIJER T, VERMEER SE, JOLLES J, KOUDSTAAL PJ, HOFMAN A, BRETELER MMB. Cerebral small-vessel disease and decline in information processing speed, executive function and memory. Brain 2005;128:2034-41.

17. ALBERS GW, CAPLAN LR, EASTON JD, FAYAD PB, MOHR JP, SAVER JL, SHERMAN DG, for the TIA Working Group. Transient ischemic attack - proposal for a new definition. $\mathrm{N}$ Engl J Med 2002;347:1715.

18. DESMOND DW. General approaches to neuropsychological assessment. In: ERKINJUNTTI T, GAUTHIER S, eds. Vascular cognitive impairment. London: Martin Dunitz, Ltd. 2002: 323-38.

19. BOTS ML, HOES AW, KOUDSTAAL PJ, HOFMAN A, GROEBBEE DE. Common carotid intima-media thickness and risk of stroke and myocardial infarction. The Rotterdam Study. Circulation 1997;96:1432-1337.

20. ALEXANDROV AV, DEMARIN V. Insonation techniques and diagnostic criteria for transcranial doppler sonography. Acta Clin Croat 1999;38:97-108.

21. LOVRENČIĆ-HUZJAN A, BOSNAR M, HUZJAN R, DEMARIN V. Frequency of different risk factors for ischemic stroke. Acta Clin Croat 1999;38:159-63.

22. RUNDEK T, DEMARIN V, KITTNER B. Impairment of cerebral vasoreactivity (CVR) in patients with multi-infarct dementia. Acta Clin Croat 1993;32:51-9.

23. BOLLER F, LOPEZ O, MOOSSY J. Diagnosis of dementia: clinicopathological correlations. Neurology 1989;38:76-9.

24. SKOOG I, GUSTAFSON D. Vascular disorders and Alzheimer's disease. In: BOWLER JW, HACHINSKI V, eds. Vascular cognitive impairment: preventable dementia. New York: Oxford University Press, 2003:261-76.

25. RILLEY KP, SNOWDON DA, MARKESBERY WR. Alzheimer's neurofibrillary pathology and the spectrum of cognitive function: findings from the Nun Study. Ann Neurol 2002;51:567-77. 
26. McKHANN G, DRACHMAN D, FOLSTEIN MF, KATZMAN R, PRICE D, STADLAN E. Clinical diagnosis of Alzheimer's disease: report of the NINCDS-ADRDA Work Group under the auspices of Department of Health and Human Services Task Force. Neurology 1984;34:939-44.

27. MARTINIĆ POPOVIĆ I, ŠERIĆ V, DEMARIN V. Mild cognitive impairment in symptomatic and asymptomatic cerebrovascular disease. Proceedings of the Fourth International Congress on Vascular Dementia, Porto, Portugal, October 23-26, 2005.

28. HEYMAN A, FILLENBAUM GG, WELSH-BOHMER KA et al. Cerebral infarcts in patients with autopsy-proven Alzheimer's disease: CERAD, part XVIII. Consortium to Establish a Registry for Alzheimer's Disease. Neurology 1998;51:159-62.
29. SNOWDON DA, GREINER LH, MORTIMER JA et al. Brain infarction and the clinical expression of Alzheimer disease. The Nun Study. J Am Med Assoc 1997;227:813-17.

30. TANG-WAI DF, KNOPMAN DS, GEDA YE et al. Comparison of the short test of mental status and the mini-mental state examination in mild cognitive impairment. Arch Neurol 2003; 60:1777-81.

31. BOWLER JV, HACHINSKI V. Vascular cognitive impairment - a new concept. In: BOWLER JW, HACHINSKI V, eds. Vascular cognitive impairment: preventable dementia. New York: Oxford University Press, 2003:231-7.

Sažetak

\title{
RANO OTKRIVANJE BLAGOG OŠTEĆENJA SPOZNAJNE FUNKCIJE U BOLESNIKA S CEREBROVASKULARNOM BOLEŠĆU
}

\author{
I. Martinić-Popović, V. Šerić i V. Demarin
}

Procjena blagog spoznajnog oštećenja je važna, jer može omogućiti rano medicinsko zbrinjavanje kako bi se spriječila teška demencija Alzheimerova ili vaskularnog tipa. U ovom probnom ispitivanju su bolesnici primljeni na Kliniku za neurologiju zbog prvog moždanog udara/prolaznog ishemijskog ispada (skupina bolesnika, $\mathrm{n}=81$, srednja dob 56 $\pm 7,0$ godina) i kontrolni ispitanici bez znakova cerebrovaskularne bolesti, ali s prisutnim vaskularnim čimbenicima rizika (kontrolna skupina, $\mathrm{n}=45$, srednja dob 53 46,0 godina) ispitani pomoću Mini Mental State Exam (MMSE) i Montreal Cognitive Assessment (MoCA) kod prijma te ponovno nakon tri i šest mjeseci. U svih osoba provedena je standardna kompjutorizirana tomografija mozga, prikaz protoka pomoću obojenog Dopplera u karotidnim arterijama uz mjerenje debljine intime medije te transkranijska Dopplerova sonografija. Višestruki rizični čimbenici bili su prisutni u $56(69,1 \%)$ bolesnika. Kontrolni ispitanici najčešće su imali arterijsku hipertenziju, hiperlipoproteinemiju i šećernu bolest. Svi ispitanici su imali normalan početni MMSE, dok je zbir MoCA bio snižen (<26 bodova) u $52(57,2 \%)$ bolesnika i $23(9,6 \%)$ kontrolne osobe. Nakon šest mjeseci je u skupini bolesnika srednji zbir MoCA bio 18,87, a srednji MMSE 25,25. Bolesnici s moždanim udarom i višestrukim čimbenicima rizika iskazali su statistički značajno spoznajno urušavanje u usporedbi s bolesnicima s prolaznim ishemijskim ispadima. U kontrolnoj skupini je najveće opadanje spoznajnih funkcija nakon šest mjeseci zabilježeno u osoba s arterijskom hipertenzijom i povećanom debljinom intime medije. U osoba s cerebrovaskularnim čimbenicima rizika rani znaci oštećenja spoznajne funkcije postoje čak i prije negoli cerebrovaskularna bolest postane klinički očita. MoCA se je pokazao odgovarajućim pomagalom za spoznajnu procjenu bolesnika s blažim oštećenjem spoznajne funkcije vaskularnog tipa.

Ključne riječi: Mozak - patologïj; Mozak - fiziopatologija; Cerebrovaskularna bolest-dijagnostika; Demencija - Alzheimerova bolest; Demencija - vaskularna demencija 